UDC 622.673.1:681.514.54

\title{
OBJECTIVE TECHNICAL MONITORING OF THE CONDITION OF THE SUCKER ROD PUMPING UNIT \\ ${ }^{1}$ Lopatin V.V. \\ ${ }^{1}$ Institute of Geotechnical Mechanics named by N. Poljakov NAS of Ukraine
}

\section{ЦІЛЬОВИЙ ТЕХНІЧНИЙ КОНТРОЛЬ СТАНУ ШТАНГИ НАСОСНОГО АГРЕГАТУ ${ }^{1}$ Лопатін В.В.}

${ }^{1}$ Інститут геотехнічної механіки ім. М.С. Полякова НАН Украӥни

\section{ЦЕЛЕВОЙ ТЕХНИЧЕСКИЙ КОНТРОЛЬ СОСТОЯНИЯ ШТАНГИ НАСОСНОГО АГРЕГАТА \\ ${ }^{1}$ Лопатин В.В. \\ ${ }^{1}$ Институт геотехнической механики им. Н.С. Полякова НАН Украинь}

Annotation. Today in Ukraine, the necessary intervals between controls, their content and volume are formed on the basis of statistical data. These statistics do not take into account the specific features of a particular SRPU, the real conditions of its operation, but only the SRPU type of SRPU type. The monitoring of SRPU, based on such monitoring and control, cannot be objective.

Objective technical monitoring and monitoring of the state of the system requires that the actual real-time state be monitored, taking into account the factor analysis, which will significantly increase its turnaround time and reduce operating costs. A four-view classification of the main methods for controlling a sucker rod pumping unit (SRPU) has been proposed. The essence of each control method of a SRPU is disclosed. Made their comparative analysis and opportunities. The vibration control and monitoring of the pumping unit gearbox of the SRPU is considered in more detail. The strategy and experiment planning of the reduction gearbox of a SRPU has been developed using factor analysis. An experimental model installation of a SRPU has been developed and created, which allows implementing the developed strategy to study the effect of gearbox defects, its operating conditions and the influence of other elements of the SRPU on the vibration characteristics of a wellbore well pumping unit. It is shown that there can be no objective control when the necessary intervals between controls, their content and volume are formed on the basis of statistical data, without taking into account the specific features of a SRPU and the real conditions of its operation, but only the type is taken into account. An objective technical monitoring of a SRPU has been proposed, which will significantly increase its overhaul mileage and reduce operating costs.

Keywords: monitoring, pumping unit, factor analysis, vibration characteristics, reduce operating costs.

Introduction. The restructuring of Ukraine's economy and its entry into the EU's economic structure consists primarily in the fact that Ukrainian output must grow faster than its costs, and that by involving significantly fewer resources in production, greater returns could be achieved. The most important condition for such restructuring and restructuring is an increase in the productivity of the enterprise and an increase in the economy mode by reducing the costs of labor, material and monetary resources. Today, more than ever, Ukraine needs new approaches that would ensure the reformation of the enterprise's production based on the acceleration of scientific and technological progress. The modern concept of the development of the oil complex of Ukraine provides for the stable supply of the country with its own oil, which largely ensures its sovereignty and independence. Most oil wells in Ukraine use SRPU.

The depreciation of fixed assets by structural units of Ukrnafta is very high, the equipment has exhausted $77 \%$ of its service life and requires high-quality repairs and the introduction of new control technologies during its operation. 


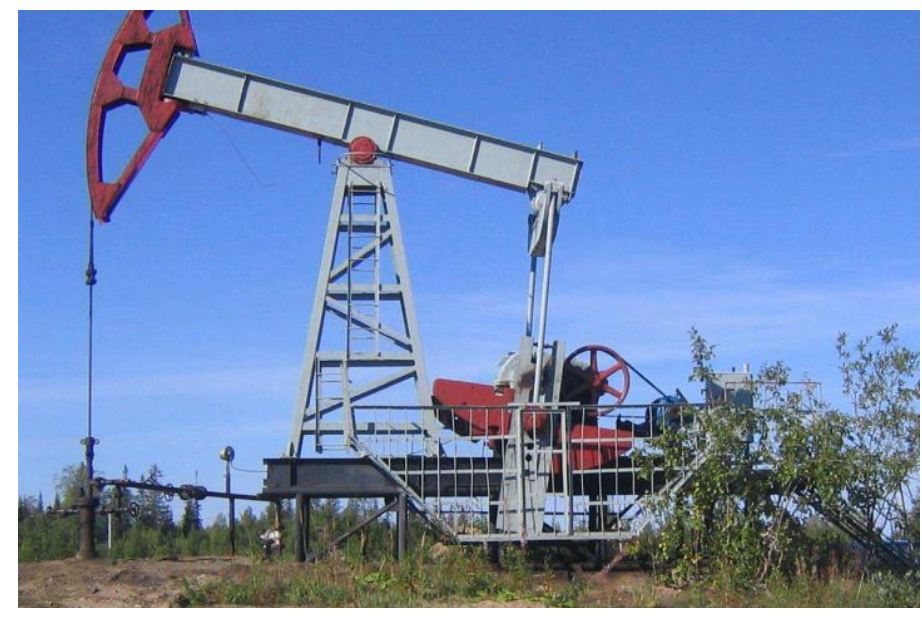

Figure 1 - Pumping unit for the SRPU at the Dolinsky oil and gas field

Regular objective monitoring of the SRPU is mandatory, as it allows timely prevention of more serious complications for the oil field. In Ukraine, the main means of monitoring the SRPU in working condition is technical monitoring, regulated by a number of regulatory and industry documents [1]. According to the author, there are four basic methods for controlling the SRPU - methods: barographing, wattmetering, vibrocontrol and dynamometering. Although there are other opinions on this issue, for example [2].

Methods. Analysis of the current state of methods for diagnosing SRPU [3, 4] shows that the most common is the dynamographic method using portable hydraulic dynamographs [3, 5-9]. The dynamographic method is based on classical mechanics with the use of removable hydraulic dynamographs mounted on a supervised unit SRPU. Original torque gauges and systems of dynamography of a well pumping unit have been developed [3, 6-12].

The barographing method controls the pressure in the suction valve and at the outlet of the SRPU sucker rod pump, the pressure drop in the valves, the nature of the leakage of the depth equipment, etc. In the case of the barographic method for monitoring the pressure, the pressure is recorded by a special depth gauge, which is lowered on the cable through the annulus of the tubing.

The method of barographing allows you to control, mainly, only the work of the deep equipment of the SRPU. In addition, a significant disadvantage of this method is its extreme complexity and laboriousness, as well as the fact that it cannot be used for operational objective monitoring of SRPU.

Wattmetric method of control is mainly based on the control of SRPU on the parameters of the power engine. Wattmetric control method allows you to control, mainly, only the work of the pumping unit that drives a deep sucker-rod pump located at the bottom of an oil well. The device of the pumping unit on the principle of action is similar to a hand pump of a bicycle, which converts reciprocating movements into air flow. The oil deep well sucker pump converts reciprocating movements from the rocking machine SRPU into a fluid flow, which flows through the tubing from the well to the surface.The wattmetric method is comparatively cheaper and requires less labor in comparison with the dynamographic method of control and 
is significantly less labor-intensive than the barographing method. However, wattmetric control methods for SRPU did not receive their distribution due to the low accuracy of the allocation of diagnostic information [3].

There have been attempts to improve and modernize the wattmetric method from the point of view of the possibility of obtaining dynamograms from wattmetric dependencies, due to the fairly widespread use of dynamographing as the main means of controlling the SRPU in oil fields $[13,14]$. However, these works did not receive further development.

Wattmetric control methods of SRPU have been used by many researchers who have developed power meter sensors and control systems [3, 13-15].

Vibration control of SRPU is a convenient and relatively inexpensive form of control of the technical condition (the lowest labor costs compared with dynamographic and wattmetric). Vibration control of SRPU is carried out with the help of removable accelerometers and tensometric sensors mounted in control points. Accuracy parameters of Vibration control are not inferior to dynamographic ones. The disadvantages of the SRPU vibration control can be attributed to the high cost of equipment and highly qualified staff.

The most common type of industrial control of the vibration state of aggregates is the determination of the root-mean-square value of the accelerometer vibration velocity and comparison with the requirements of international standards ISO 2372, SO 2373 or others, or regulatory documents based on them [7].

The ground equipment of SRPU includes a pumping unit, which provides reciprocating rods. There is a significant number of designs of pumping units, which differ in the kinematic scheme [14]. In works [3, 15-21] mathematical diagnostic models of a pumping unit for various kinematic schemes with a different degree of simplification and taking into account various factors of influence are given.

Results and discussion. Vibration is one of the most important factors that influences the technical characteristics of SRPU equipment. For example, the operation of any gear pair of the SRPU gearbox is accompanied by a number of characteristic vibrations that arise as a result of friction and shock during operation. The technical condition of any, even almost perfectly made gear pair, can be assessed in the process of work with the help of vibration signal analysis.

During operation, there are continuous changes in the technical condition of gearboxes under the influence of various operational factors. Excessive vibration during the operation of the gearbox leads to a quick response of its parts, reduces the efficiency of the work of SRPU and leads to emergency situations. Thus, the vibration level should be minimal, which will ensure the necessary duration of operation of the gearboxes. For example, the quality of the repair performed by the SRPU gearbox should be checked in conditions close to operational conditions with appropriate accuracy.

At the same time you need:

- strive to minimize the total number of experiments;

- choose a clear strategy that will allow you to make appropriate decisions after each series of experiments; 
- use a mathematical apparatus that formalizes most of the actions of the experimenter;

- to develop a strategy for the simultaneous manipulation of all the variables defining the process, according to special rules - algorithms.

The search for optimal conditions for the influence of experimental factors on the magnitude of the vibration of the SRPU gearbox is one of the important scientific and technical problems.

We will plan the experiment of the reducer of SRPU using factor analysis.

Factor analysis allows to solve two important problems of the researcher: to describe the vibration of the SRPU reducer comprehensively and at the same time compactly. Using factor analysis, it is possible to identify hidden variables responsible for the presence of linear statistical correlations between the observed variables.

The two main goals of factor analysis are:

- definition of interrelations between variables, (classification of variables);

- reducing the number of variables required to describe the data.

In the analysis, the variables that are strongly correlating among themselves are combined into one factor, as a result, the redistribution of dispersion between the components occurs and the structure of the factors is as simple and clear as possible. After combining, the correlation of components within each factor among themselves will be higher than their correlation with components from other factors. This procedure also allows you to select latent variables. Thus, the goal of factor analysis is to find such complex factors that best explain the relationships between the variables that are being studied. When planning experiments, we implement a full factorial experiment of type 22 .

The first stage of planning an experiment to obtain a linear model is based on the manipulation of factors at two levels. So, as the number of factors is known, one can immediately find the number of experiments necessary for the realization of all possible levels of factors.

The level of vibration velocity is selected as the output parameter when building the regression equation. The levels of factors and the intervals of their changes are shown in table 1.

Table 1 - Levels of factors and intervals of their change

\begin{tabular}{|c|c|c|c|c|}
\hline \multirow{2}{*}{ Factors } & \multicolumn{3}{|c|}{ Levels } & \multirow{2}{*}{ Intervals } \\
\cline { 2 - 4 } & -1 & 0 & +1 & 260 \\
\hline $\mathrm{X}_{1}$ - SRPU hours of work, hours & 10 & 270 & 530 & 200 \\
\hline $\begin{array}{c}\mathrm{X}_{2} \text { - load effect at the suspension point } \\
\text { of the rods, } \mathrm{N}\end{array}$ & 100 & 300 & 500 & \\
\hline
\end{tabular}

The experimental conditions are written in the form of a planning matrix for two factors in Table 2, where each ruler corresponds to different experiments, and the columns correspond to the values of the factors. Thus, we have two vectors - columns of independent variables and one column vector of the optimization parameter. 
As a result of the experiments performed on the stand using the planning matrix (Table 2), we find the regression equation, which is a mathematical model of the influence of these factors on the magnitude of the vibration velocity.

Table 2 - Experiment Planning Matrix $2^{2}$

\begin{tabular}{|c|c|c|c|c|c|}
\hline Factornumber & $X_{o}$ & $X_{1}$ & $X_{2}$ & $X_{1} X_{2}$ & $Y(\mathrm{~mm} / \mathrm{s})$ \\
\hline 1 & + & $-(10)$ & $-(100)$ & + & 0.289 \\
\hline 2 & + & $+(530)$ & $-(100)$ & - & 2.25 \\
\hline 3 & + & $-(10)$ & $+(500)$ & + & 0.496 \\
\hline 4 & + & $+(530)$ & $+(500)$ & - & 2.75 \\
\hline
\end{tabular}

To move to the optimal point, you need a linear model $y=b_{o}+b_{1} x_{1}+b_{2} x_{2}$. According to the results of the experiment, we find the values of the unknown coefficients of the model $b_{0}, b_{1}$ and $b_{2}$

$$
\begin{aligned}
& \mathrm{b}_{1}=\frac{(-1) y_{1}+(+1) y_{2}+(-1) y_{3}+(+1) y_{4}}{4} \\
& \mathrm{~b}_{2}=\frac{(-1) y_{1}+(-1) y_{2}+(+1) y_{3}+(+1) y_{4}}{4}
\end{aligned}
$$

To calculate the coefficient of the model $b_{1}$, the column vector $x_{1}$ is used, and for $\mathrm{b}_{2}$, the column $x_{2}$ is used.

$$
\begin{aligned}
& \mathrm{b}_{1}=\frac{(-1) 0.289+(+1) 2.25+(-1) 0.446+(+1) 2.75}{4}=1.066 \\
& \mathrm{~b}_{2}=\frac{(-1) 0.289+(-1) 2.25+(+1) 0.446+(+1) 2.75}{4}=0.16
\end{aligned}
$$

It remains to find $b_{o}$. If the equation $y=b_{o}+b_{1} x_{1}+b_{2} x_{2}$ is true, then it will be correct for arithmetic means of variables. Therefore

$$
\mathrm{b}_{0}=\frac{0.289+2.25+0.446+2.75}{4}=1.43
$$

The coefficients of independent variables indicate the strength of influence of factors. The greater the magnitude of the coefficient, the more influenced the factor. In this case, because since the coefficient has a plus sign, then with an increase in the value of the factor, the optimization parameter increases. Since one factor depends on the level at which the second factor is located, we use the effect of the interaction of two factors. Then the model will look like this $y=b_{o}+b_{1} x_{1}+b_{2} x_{2}+b_{12} x_{1} x_{2}$. To do this, determine the coefficient of the interaction effect $b_{12}$. 
ISSN 1607-4556 (Print), ISSN 2309-6004 (Online) Геотехнічна механіка. 2018. №142

$$
\begin{gathered}
\mathrm{b}_{12}=\frac{(+1) y_{1}+(-1) y_{2}+(+1) y_{3}+(-1) y_{4}}{4}= \\
=\frac{(+1) 0.289+(-1) 2.25+(+1) 0.446+(-1) 2.75}{4}=-1.06
\end{gathered}
$$

The combined effect of two factors reduces the level of vibration velocity, since the value of the coefficient of interaction effect $b_{12}$ is negative.

The regression equation using the scheduling matrix will be

$$
y=1.43+1.066 x_{1}+0.16 x_{2}-1.06 x_{1} x_{2}
$$

The regression equation shows that decreasing the factors $x 1$ (i.e., the duration of the work) leads to a decrease in the optimization parameter y (i.e. the level of vibration velocity). The experiments were carried out on a specially designed and manufactured installation (Fig. 2) to study the effect of gearbox defects, its working conditions and the effect of other elements of the pumping unit on the vibration characteristics of the SRPU.

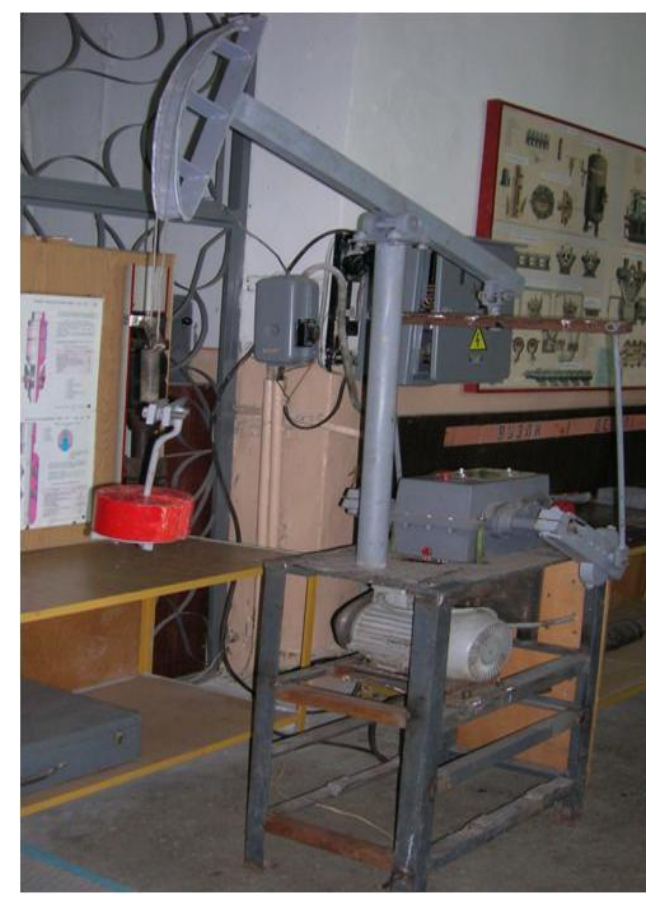

Figure 2 - Experimental model installation SRPU

The physical similarity of real vibrations of SRPU, is carried out in the model, between the parameters of the object and its dimensional processes, which are investigated. Such quantities characterizing processes differ only in scale, and the characteristics of one process can unambiguously get the characteristics of the others.

In the conducted research, the SRPU focuses attention on the magnitude of the vibration amplitude during the action of various factors during the SRPU operation, which are determined by the value of vibration velocity.

Physical modeling of the vibration state of the SRPU reducer was performed by the method of conjugate dimensional quantities based on the Lagrange method, taking into account the factor analysis described above.

An experimental model set-up was created to carry out physical modeling, that is, the replacement of a physical process studied by a process of the

same physical nature, similar to it.

An experimental model installation preserves the physical similarity of the model processes to those processes that actually arise in the SRPU. As can be seen in Figure 3 and Figure 4, they are almost identical. Thus, the experimental model installation was verified and the physical similarity of the real vibrations of SRPU was obtained. 


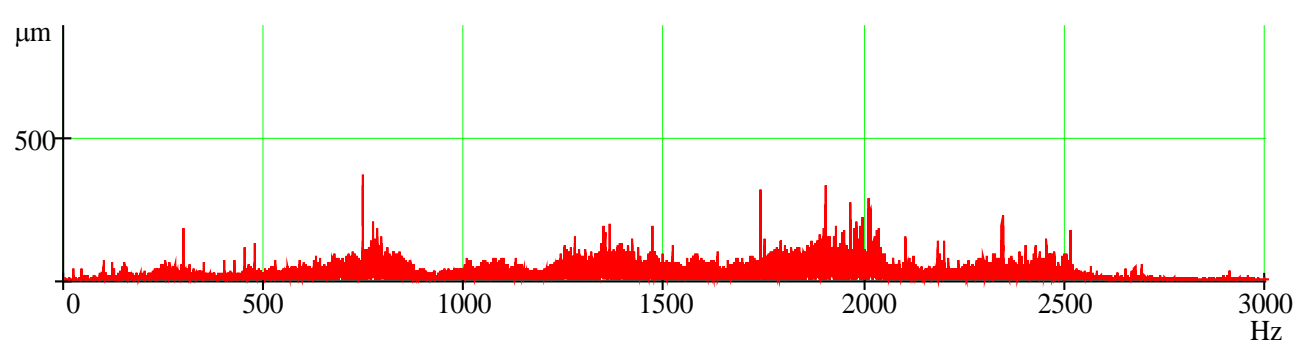

Figure 3 - Vibration spectrum of SRPU on an experimental model setup

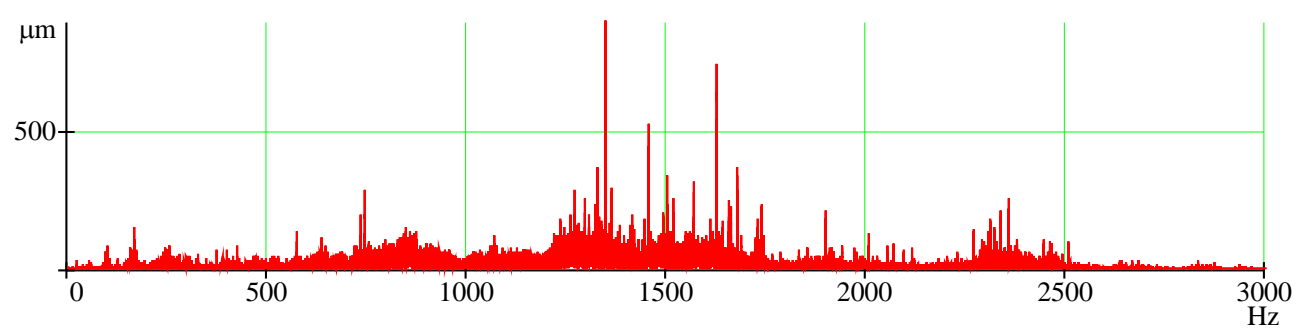

Figure 4 - Spectrum of actual vibrations of a real SRPU at the Dolinsky oil and gas field

Conclusions. Today in Ukraine, the necessary intervals between controls, their content and volume are formed on the basis of statistical data. These statistics do not take into account the specific features of a particular SRPU, the real conditions of its operation, but only the SRPU type of SRPU type. The monitoring of SRPU, based on such monitoring and control, cannot be objective.

Objective technical monitoring and monitoring of the state of the system requires that the actual real-time state be monitored, taking into account the factor analysis, which will significantly increase its turnaround time and reduce operating costs.

\section{REFERENCES}

1. Ukraine Standard Office (1995), DSTU 2865-94. Kontrol neruynivnyi. Derzhavnyi standart Ukrainy [2865-94. Non-destructive control. State Standard of Ukraine], Derzhstandart Ukrainy, Kiev, Ukaine.

2. TNPVO "SIAM" (2006), Kontrol raboty burovogo nasosa. Kompleks SIDDOS [Control of drill deep pump operation. Complex SIDDOS], Izdatelstvo TNPVO "SIAM", Tomsk, Russia.

3. Zamihovsky, L. M., RovinskyV. A. and Yevchuk O.V. (2006), Diagnostika tekhnichnogo stanu shtangovykh glybynnoOnasosnykh ustanovok [Diagnosis of the technical state of deep-pumping units], Simfoniya Forte, Ivano-Frankivsk, Ukraine

4. Karpash, O. M. (1997), "Non-destructive testing and technical diagnostics of oil and gas equipment and tools Nondestructive testing and technical diagnostics", Matetials 2 nd Ukrainian Science. Tech. conf. Dnipropetrovsk, p. 36.

5. Aliyev, T. M., Nadein, V. A., Rysikin, L. M. and Ter-Khachaturov, A. A. (1981), "Methods and means for controlling the technical condition of deep-pumping equipment", Neftyanoe khozyaistvo, no. 5, pp. 57-59.

6. Lea, J. F., Winkler, H. V. and Snyder, R. E. (2000), "What's new in artificial lift", Word Oil, no. 221 (3), p.74.

7. Gaus, P.O., Lavrov, V.V. and Nalimov G.P. (2000), "Diagnostic capabilities of monoblock electronic dynamometers "SIDDOS-Avtomat", Neftyanoe khozyaistvo, no. 7, pp. 87-88. 2018).

8. UraINITI (2018), "Electronic portable dynamometer system "URAN-100", available at: http: //uralniti.ru/, (Accessed 6 July

9. Kvantor-T (2018), "Mobile hardware and software complex of diagnostics of wells "Kvantor-3", available at: http://www.sprut.ru/quantor-t/prod.htm, (Accessed 6 July 2018).

10. Barker CAC (1996), "Equipment and software for well control and control: Catalog of the company "Barker CAC", Printed in the USA, New-York, USA.

11. Mikron (2018), "Dynamograph built-in micron-802", available at: http://www micron.rul, (Accessed 6 July 2018).

12. PAK "KDS" (2012), "Software and hardware complex of research and diagnostics of SHNU", available at: http://www.neftegazprogress.ru/nauka-dneft.html, (Accessed 12 December 2016).

13. Texac Instruments (2012), "MSP-430 DataBook. Applikation Examples. Electricity Meters. Chapter 4", available at: http://www.it.com, (Accessed 12 December 2016).

14. Barnes, et al. (2007), Integrated control system for beam pump systems, USA, Pat. № 7219723.

15. Svetlakova, S. V.(2008), "Information-measuring system of dynamometry of wells, equipped with rods deep pumps", Abstract of Ph.D. dissertation, tech sciences 11.05.16, Ufa, Russia. 
16. Lopatin, V. V., Kopey, B. V. and Stefanyshin, O.I. (2010), Mobilnye izmeritelnye sistemy $v$ neftegazovoy $i$ gornodobyvayushchey promyshlennosti, [Mobile measurement systems in the oil and gas and mining industry. Monograph], IFNTUNG, Ivano-Frankivsk, Ukraine.

17. Lopatin, V.V. (2013), "Scientific bases for the development of a system for monitoring the technical condition of the hardening of shaft trunks", D.Sc. Thesis, Instruments and methods for controlling and determining the composition of substances, Ivano-Frankivskiy National Technical University of Oil and Gas, Ivano-Frankivsk, Ukraine

18. Lopatin, V. and Leshchynskyi, S. (2016), "Outstanding issues means of objective control problem in mines", Promoting robust ethical practices for the extractive industries, Johannesburg, South Africa, 15-17 February 2016.

19. Lopatin, V. V. (2016), "Objective technical monitoring and diagnostics of the condition of gearboxes of well bore pumping station", Materialy mezhdunarodnoy nauchno-tekhnicheskoy konferentsii [Materials of the international scientific and technical conference], Mashyny, obladnannya ta materialy dlya zbilshennya vnutrishnogo vyrobnytstva ta dyversyfikatsiyi postachannya nafty i hazu [Machines, equipment and materials for increasing domestic production and diversification of oil and gas supply], Ivano-Frankivsk, p. $191-194$

20. Watson, et al. (2005), "Reciprocating pump control system", USA, Pat. №6890156.

21. Ananiev, V. D., Sizarev, V. D. et.al. (2015), "Problems of nuclear power facility vibroacoustic diagnostics", Proc. of the topical seminar on management of ageing of research reactors, Geesthacht, Hamburg, IAEA, Vienna, Austria, p.485-494.

\section{СПИСОК ЛІТЕРАТУРИ}

1. ДСТУ 2865-94. Контроль неруйнівний. Терміни та визначення. Київ, 1995. 12 с.

2. Контроль работы бурового насоса. Комплекс SIDDOS. Томск: Изд-во ТНПВО «СИАM». 26 с.

3. Заміховський Л.М., Ровінський В.А., Євчук О.В. Діагностика технічного стану штангових глибинно-насосних установок: монограффія. Івано-Франківськ: Симфонія форте, 2006. 308 с.

4. Карпаш О.М. Неразрушающий контроль и техническая диагностика нестегазового оборудования и инструментов // Неразрушающий контроль и техническая диагностика: Материалы технической конференции. Днепропетровск, 1997. с. 36.

5. Алиев Т. М., Надеин В. А., Русикин Л. М., Тер-Хачатуров А. А. Методы и средства контроля технического состояния оборудования глубокой закачки / Нефтяное хозяйство. 1981. №5. С. 57-59.

6. Lea J. F., Winkler H. V., Snyder R. E. What’s new in artificial lift / Word Oil. 2000. № 221 (3). P.74.

7. Гаус П.О., Лавров В.В., Налимов Г.П. Диагностические возможности моноблочных электронных динамометров «СИДОСС-Автомат» / Нефттяное хозяйство. 2000. № 7. С. 87-88.

8. Электронная портативная динамометрическая система «УPAH-100». URL: http: //uralniti.ru/ (дата обращения 06.07.2018).

9. Мобильный аппаратно-программный комплекс диагностики скважин «Квантор-3». URL:http://www.sprut.ru/quantort/prod.htm, (дата обращения 06.07.2018.

10. Equipment and software for well control and control: Catalog of the company "Barker CAC". New-York: Printed in the USA, 1996. $21 \mathrm{p}$.

11. Динамографр встроенный микрон-802. URL: http://www micron.ru/ (дата обращения 06.07.2018).

12. Программно-технический комплекс исследования и диагностики ШНУ. URL: http://www.neftegazprogress.ru/naukadneft.html, (дата обращения 12.12.2016).

13. MSP-430 DataBook. Applikation Examples. Electricity Meters. Chapter 4. URL: http://www.it.com, (дата обращения 12.12.2016).

14. Barnes et al. (2007), Integrated control system for beam pump systems: Pat. USA № 7219723 ; 22.05.2007.

15. Светлакова С.В. Информационно-измерительная система динамометрии скважин, оборудованная стержнями глубинных насосов: автореф. дисс. ...канд. техн. наук / Спец. 11.05.16. Уфа: УГНТУ, 2008. 19 с.

16. Лопатин В.В., Копей Б.В., Стефранишин О. И. Мобільні вимірювальні системи в нафтогазовій та гірничій промисловості. Монограффія. Івано-Франківськ: ІФНТУНГ, 2010. 392 с.

17 Лопатін, В.В. Наукові основи розроблення системи контролю технічного стану жорсткого армування шахтних стовбурів. Автореферат дис. доктора техн. наук / Спец. 05.11.13. Івано-Франківськ: ІФНТУ, 2013. 34 с.

18. Lopatin V., Leshchynskyi S. Outstanding issues means of objective control problem in mines / Promoting robust ethical practices for the extractive industries. Johannesburg, South Africa, 15-17 February 2016.

19. Лопатин В.В. Целевой технический мониторинг и диагностика состояния редукторов скважинной насосной станции / Материалы международной научно-технической конференции «Машины, оборудование и материалы для увеличения отечественного производства и диверсификации поставок нефти и газа», Ивано-Франковск. 2016. С.191-194.

20. Watson et al. Reciprocating pump control system: Pat. USA №6890156. 10.05.2005.

21. Problems of nuclear power facility vibroacoustic diagnostics" / Ananiev V. D., Sizarev V. D. et.al. // Proc. of the topical seminar on management of ageing of research reactors, Geesthacht, Hamburg, IAEA, Vienna, Austria. 2015. P.485-494.

\section{About the author}

Lopatin Valeriy Volodymyrovych, Doctor of Technical Sciences (D.Sc.), Senior Researcher, Senior Researcher in Department of Geodynamic Systems and Vibration Technologies, M.S. Polyakov Institute of Geotechnical Mechanics NAS of Ukraine (IGTM, NAS of Ukraine), Dnipro, Ukraine, vlop@ukr.net. 


\section{Про автора}

Лопатін Валерій Володимирович, доктор технічних наук, старший науковий співробітник, старший науковий співробітник відділу Геодинамічних систем і вібраційних технологій, Інститут геотехнічної механіки ім. М.С. Полякова Національної академії наук України (ІГТМ НАН України), Дніпро, Україна, vlop@ukr.net.

Анотація. Сьогодні в Україні необхідні інтервали між контролями, їх змістом і обсягом формуються на основі статистичних даних. Ця статистика не враховує специфічні особливості конкретної насосної установки насосної штанги (НУНШ), реальні умови його роботи, а тільки тип НУНШ. Контроль НУНШ, заснований на такому моніторингу та перевірці, не може бути об'єктивним.

Об'єктивний технічний контроль і моніторинг стану системи вимагає, щоб фактичний стан в режимі реального часу контролювався з урахуванням факторного аналізу, що значно збільшить час його виконання і скоротить експлуатаційні витрати.

Запропоновано класифікацію основних методів управління насосною установкою насосної штанги з чотирма видами. Розкрито сутність кожного методу управління НУНШ. Зроблено порівняльний аналіз їх можливостей. Кон-троль вібрації і контроль редуктора насосного агрегату НУНШ розглянуто більш докладно. Стратегія і планування експерименту редуктора НУНШ були розроблені з використанням факторного аналізу. Розроблено та створено експериментальну модельну установку НУНШ, що дозволяє реалізувати розроблену стратегію з вивчення впливу дефектів коробки передач, умов їі експлуатації і впливу інших елементів НУНШ на вібраційні характеристики насосного агрегату стовбура свердловини. Показано, що не може бути об'єктивного контролю, коли необхідні інтервали між контролями, їх змістом і обсягом фрормуються на основі статистичних даних, без урахування специфічних особливостей НУНШ і реальних умов його роботи, коли враховується тільки тип обладнання. Запропоновано об'єктивний технічний моніторинг НУНШ, який значно збільшить термін експлуатації до капітального ремонту і знизить експлуатаційні витрати.

Ключові слова: контроль, насосна установка, факторний аналіз, вібраційні характеристики, зниження експлуатаційних витрат.

Аннотация. Сегодня в Украине необходимые интервалы между контролями, их содержанием и объемом формируются на основе статистических данных. Эта статистика не учитывает специфические особенности конкретного насосной установкой насосной штанги (НУНШ), реальные условия его работы, а только тип НУНШ. Контроль НУНШ, основанный на таком мониторинге и проверке, не может быть объективным.

Объективный технический контроль и мониторинг состояния системы требует, чтобы фрактическое состояние в режиме реального времени контролировалось с учетом факторного анализа, что значительно увеличит время его выполнения и сократит эксплуатационные расходы.

Предложена классисикация основных методов управления насосной установкой насосной штанги с четырьмя видами. Раскрыта сущность каждого метода управления НУНШ. Сделан сравнительный анализ их возможностей. Контроль вибрации и контроль редуктора насосного агрегата НУНШ рассмотрен более подробно. Стратегия и планирование эксперимента редуктора НУНШ были разработаны с использованием фракторного анализа. Разработана и создана экспериментальная модельная установка НУНШ, позволяющая реализовать разработанную стратегию по изучению влияния дефектов коробки передач, условий ее эксплуатации и влияния других элементов НУНШ на вибрационные характеристики насосного агрегата ствола скважины. Показано, что не может быть объективного контроля, когда необходимые интервалы между контролями, их содержанием и объемом формируются на основе статистических данных, без учета специфических особенностей НУНШ и реальных условий его работы, когда учитывается только тип оборудования. Предложен объективный технический мониторинг НУНШ, который значительно увеличит срок эксплуатации до капитального ремонта и снизит эксплуатационные расходы.

Ключевые слова: контроль, насосная установка, факторный анализ, вибрационные характеристики, снижение эксплуатационных расходов.

Стаття надійшла до редакиії 23.11.2018

Рекомендовано до друку д-ром техн. наук, профр. Мінєєвим С.П. 